\title{
An Empirical Study on the Coordinated Development of Economy and Ecological Environment of Eastern City Group in Qinghai Province
}

\author{
Yatian Liu ${ }^{1, a}$, Shengxi Ding ${ }^{2 *}$ \\ ${ }^{1}$ College of Finance and Economics, Qinghai University, Qinghai, Xining, China \\ ${ }^{2}$ College of Finance and Economics, Qinghai University, Qinghai, Xining, China
}

\begin{abstract}
Firstly, this article uses the Entropy method to calculate the weights of economic development and ecological environment indicators in the eastern urban agglomeration of Qinghai Province from 2005 to 2019. Secondly, this article uses the calculated weights and linear weighting functions to construct evaluation models for economic development and ecological environment development, respectively. The results show that the comprehensive development level of the economic development in the eastern urban agglomeration of Qinghai Province cities is gradually rising, and the comprehensive development level of the ecological environment fluctuates slightly but the overall development trend is increasing. Then, using the Environmental-Economic Coordination degree evaluation model, quantitative analysis and evaluation of the Environmental-Economic system coordination degree, it is found that the coordinated development of the economic and ecological environment of the eastern urban agglomeration in Qinghai Province is relatively well. Finally, it analysis and proposes countermeasures and suggestions to promote the coordinated development of the economic and environmental system of the eastern urban agglomeration in Qinghai Province.
\end{abstract}

\section{Introduction}

In 2020, the main goal of economic and social development during the "14th Five-Year Plan" period are to achieve sustained and healthy economic development on the basis of a significant improvement in quality and efficiency; and comprehensively promote green development. At the same time, the "Xining-Haidong Metropolitan Area" in Qinghai Province is being developed in an orderly manner, expanding new space for regional development, realizing coordinated and integrated development, so as to promote the coordinated and integrated development of city cluster nodes, and actively cultivate a number of emerge cities.

Since the implementation of the Western Development Strategy, the total economic volume of the western region of my country has increased rapidly, but serious environmental pollution problems have subsequently arisen. ${ }^{[1-7]}$ The ecological economic development of Qinghai Province is unevenly distributed, the ecological environment of the eastern urban agglomeration is in a dangerous state, and there is a certain gap between the coordination of regional economy, economic high-quality development and ecological environment and high-quality coordinated development. ${ }^{[8-13]}$ Therefore, it is urgent to seek measures to improve the level of coordinated development based on the objective evaluation of the degree of coordination between the economic and ecological environment of the eastern urban agglomeration in Qinghai Province.

\section{Development status of the Eastern City Group in Qinghai Province}

The eastern urban agglomeration of Qinghai Province consists of two prefecture-level cities-Xining City and Haidong City, with 7 districts and 7 counties, with a total area of 20,860 square kilometers and a total population of $3,819,477$ people.

Since the western development, the economic development of the eastern urban agglomeration of Qinghai Province has been rapid. In 2005, Xining's GDP was 20.627 billion yuan, the added value of the secondary industry was 10.978 billion yuan, and the added value of the tertiary industry was 8.499 billion yuan; Haidong's GDP was 7.419 billion yuan, and the secondary industry's added value was 2.866 billion yuan. The added value of the tertiary industry was 3.024

\footnotetext{
a First author: Yatian Liu, Postgraduate study the Field Regional Economics. E-mail: 1yt815901500@gmail.com

${ }^{*}$ Corresponding author: Shengxi Ding, Professor. Master Instructor research Regional economic development and urbanization. E-mail: qhdxjjxdsx@126.com
} 
billion yuan. In 2019. Xining's GDP was 138.289 billion yuan, the secondary industry's added value was 49.654 billion yuan, and the tertiary industry's added value was 84.417 billion yuan; Haidong's GDP was 48.773 billion yuan, and the secondary industry's added value was 18.492 billion yuan. The added value was 23.236 billion yuan. It can be seen that the economy of the eastern urban agglomeration of Qinghai Province is growing rapidly, and the tertiary industry are gradually occupying a leading position in the industrial structure. At the same time, Qinghai Province insists on scientific development, and its environmental protection has been continuously strengthened. In 2005, Xining City's waste water discharge amounted to 267.79 million tons per year, industrial water consumption was 259 million cubic meters, and ecological environment water consumption was 100.5 million cubic meters; Haidong City's waste water discharge volume was 45.56 million tons per year, and industrial water consumption was 40 million cubic meters, and the ecological environment water consumption is 0 billion cubic meters. In 2018, Xining City's waste water discharge volume was 146.26 million tons per year, industrial water consumption was 91 million cubic meters, and ecological environment water consumption was 23 million cubic meters; Haidong City's waste water discharge volume was 45.2 million tons per year, and industrial water consumption was 30 million cubic meters, and the ecological environment water consumption is 38 million cubic meters. ${ }^{[14-17]}$ It can be seen that the urban agglomerations of eastern Qinghai Province pay more attention to the ecological environment, strictly control the discharge of waste water and industrial water consumption, and increase the water consumption of the ecological environment.

\section{Establishment of the evaluation indexes system for the economic and ecological environment development of the Eastern City Group in Qinghai Province}

\subsection{Principles of establishing evaluation index system}

The construction of an indicator system for coordinated economic-ecological environment development should conform to scientific, systematic and universal principles, and important indicators should be selected through research.

\subsection{Framework of evaluation index system}

Construct a three-level economic and ecological environment system evaluation system, namely the target level, the criterion level, and the index level. The economic development index targets construct its criterion layer from the aspects of total economic scale, economic structure characteristics, and socio-economic construction, and the environmental system development target constructs its criterion layer from the aspects of environmental pollution status and ecological environment endowment. Under the standard level, 19 indicators including per capital GDP and industrial water consumption are set. The indicator system is shown in Table 1.

\subsection{Data source}

The data selected in this article are mainly derived from the 2005-2019 Statistical Yearbook of Qinghai Province, the Statistical Bulletin of the National Economic and Social Development of Xining City, the Statistical Bulletin of the National Economic and Social Development of Haidong City, and the Bulletin of the State of the Ecological Environment in Qinghai Province. "Qinghai Province Water Resources Bulletin" and others, for the data that still cannot be directly obtained, MATLAB interpolation and polynomial fitting methods are used to assign missing indicators to fill in the gaps.

Table 1. Evaluation indexes system for the coordinated

development of economic development and ecological environment in the eastern urban agglomeration of Qinghai Province

\begin{tabular}{|c|c|c|}
\hline $\begin{array}{l}\text { Criterion } \\
\text { layer }\end{array}$ & $\begin{array}{l}\text { Index } \\
\text { layer }\end{array}$ & Unit \\
\hline \multirow{10}{*}{$\begin{array}{c}\text { economy } \\
\text { development }\end{array}$} & $\begin{array}{l}\text { GDP per capita } \\
\left(\mathrm{X}_{1}\right)\end{array}$ & (Yuan/person) \\
\hline & $\begin{array}{l}\text { GDP growth rate } \\
\qquad\left(\mathrm{X}_{2}\right)\end{array}$ & $(\%)$ \\
\hline & $\begin{array}{l}\text { The added value } \\
\text { of the secondary } \\
\text { industry as a } \\
\text { proportion of } \\
\text { GDP }\left(\mathrm{X}_{3}\right)\end{array}$ & $(\%)$ \\
\hline & $\begin{array}{l}\text { The added value } \\
\text { of the tertiary } \\
\text { industry as a } \\
\text { proportion of } \\
\text { GDP }\left(\mathrm{X}_{4}\right)\end{array}$ & $(\%)$ \\
\hline & $\begin{array}{c}\text { The total retail } \\
\text { sales of social } \\
\text { consumer goods } \\
\left(\mathrm{X}_{5}\right)\end{array}$ & (Billion) \\
\hline & $\begin{array}{l}\text { The city's total } \\
\text { consumer price } \\
\text { increase }\left(\mathrm{X}_{6}\right)\end{array}$ & $(\%)$ \\
\hline & $\begin{array}{c}\text { Fixed asset } \\
\text { investment } \\
\left(\mathrm{X}_{7}\right)\end{array}$ & (Billion) \\
\hline & $\begin{array}{l}\text { Urbanization rate } \\
\text { of permanent } \\
\text { population } \\
\left(\mathrm{X}_{8}\right)\end{array}$ & $(\%)$ \\
\hline & \begin{tabular}{l}
\multicolumn{1}{c}{ Per capita } \\
disposable \\
income of urban \\
residents $\left(\mathrm{X}_{9}\right)$
\end{tabular} & (Yuan/person) \\
\hline & Per capita & (Yuan/person) \\
\hline
\end{tabular}




\begin{tabular}{|c|c|c|}
\hline & $\begin{array}{c}\text { disposable } \\
\text { income of } \\
\text { farmers }\left(X_{10}\right)\end{array}$ & \\
\hline \multirow{9}{*}{$\begin{array}{l}\text { ecological } \\
\text { environment }\end{array}$} & $\begin{array}{l}\text { Industrial water } \\
\text { consumption } \\
\left(\mathrm{Y}_{1}\right)\end{array}$ & $\left(\right.$ Billion $\left.\mathrm{m}^{3}\right)$ \\
\hline & $\begin{array}{l}\text { Ecological water } \\
\text { consumption } \\
\left(\mathrm{Y}_{2}\right)\end{array}$ & $\left(\right.$ Billion $\left.\mathrm{m}^{3}\right)$ \\
\hline & $\begin{array}{l}\text { Total water } \\
\text { resources }\left(\mathrm{Y}_{3}\right)\end{array}$ & $\left(\right.$ Billion $\left.\mathrm{m}^{3}\right)$ \\
\hline & $\begin{array}{l}\text { Wastewater } \\
\text { discharge from } \\
\text { the secondary } \\
\text { industry }\left(\mathrm{Y}_{4}\right)\end{array}$ & $\begin{array}{l}\text { (10000 tons per } \\
\text { year) }\end{array}$ \\
\hline & $\begin{array}{c}\text { Discharge of } \\
\text { tertiary industry } \\
\text { wastewater } \\
\left(\mathrm{Y}_{5}\right)\end{array}$ & $\begin{array}{l}\text { (10000 tons per } \\
\text { year) }\end{array}$ \\
\hline & $\begin{array}{l}\text { The proportion } \\
\text { of chemical } \\
\text { oxygen demand } \\
\text { emissions in the } \\
\text { province }\left(\mathrm{Y}_{6}\right)\end{array}$ & $(\%)$ \\
\hline & $\begin{array}{l}\text { The proportion } \\
\text { of } \mathrm{SO} 2 \\
\text { emissions in the } \\
\text { province }\left(\mathrm{Y}_{7}\right)\end{array}$ & $(\%)$ \\
\hline & $\begin{array}{c}\text { Total cultivated } \\
\text { land resources } \\
\left(\mathrm{Y}_{8}\right)\end{array}$ & (Hectares) \\
\hline & $\begin{array}{c}\text { Fertilizer } \\
\text { application rate } \\
\left(\mathrm{Y}_{9}\right)\end{array}$ & $\begin{array}{l}\text { (Physical } \\
\text { tons) }\end{array}$ \\
\hline
\end{tabular}

\section{Evaluation of the coordinated development of the economy and ecological environment of the Eastern City Group in Qinghai Province based on the entropy method}

In this study, the entropy method is used to process the data to obtain the required weight. In information theory, entropy is a measure of the degree of disorder in the system, which can be used to measure the amount of effective information contained in known data and determine the weight, and provide a basis of comprehensive evaluation of multiple indicators. The calculation results are shown in Table 2 and Table 3; then comprehensive development the calculation results are shown in Table 4; the coordination degree and coordinated development level of the eastern urban agglomeration in Qinghai Province are finally obtained. The calculation results are shown in Tables 5 and 6 .

From Table 4, it can be seen that the comprehensive economic development level of the eastern urban agglomeration of Qinghai Province is gradually rising and the upward trend is stable; the comprehensive development level of the ecological environment is rising in waves, although there have been fluctuations in the interim, the overall The overall economic development level of Xining City is higher than that of Haidong City, and the comprehensive development level of the ecological environment of Haidong City is higher than Xining City.

It can be seen from Table 5 that the coordination level of the eastern urban agglomerations of Qinghai Province was relatively good at 2005-2019. After 2007, high-quality coordination exceeded good coordination. This proves that after 2007, the eastern urban agglomerations of Qinghai Province paid more attention High-quality economic development. During these fifteen years, the coordinated economic and ecological development of the eastern urban agglomeration in Qinghai Province was unstable and the development speed was inconsistent, mainly manifested in the lagging ecological environment.

From Table 6 the level of coordinated development of the eastern urban agglomeration of Qinghai Province, it can be seen that from 2005 to 2007, the level of coordination was low, manifested as out-of-alignment and on the verge of out-of-alignment; after 2007, the level of coordination gradually increased, and it was shown as good coordination in 2019. It proves that during this twelve-year period, the development of the eastern urban agglomeration of Qinghai Province is now paying more attention to the governance of the ecological environment and the coordination between the economy and the ecological environment. The eastern urban agglomeration of Qinghai Province must pay more attention to the upgrading of the economic system, improve the quality of economic development, and at the same time increase the efforts to improve the ecological environment, in order to promote the coordinated development of the environment and economy.

Table 2. The economic development index weights of the eastern urban agglomeration in Qinghai Province

\begin{tabular}{|c|c|c|}
\hline $\begin{array}{c}\text { Economic } \\
\text { Indicators }\end{array}$ & Xining & Haidong \\
\hline $\mathrm{X}_{1}$ & 0.0894870 & 0.099455 \\
\hline $\mathrm{X}_{2}$ & 0.0654350 & 0.065907 \\
\hline $\mathrm{X}_{3}$ & 0.0665730 & 0.110559 \\
\hline $\mathrm{X}_{4}$ & 0.0149858 & 0.065712 \\
\hline $\mathrm{X}_{5}$ & 0.1001030 & 0.098488 \\
\hline $\mathrm{X}_{6}$ & 0.0655240 & 0.128173 \\
\hline $\mathrm{X}_{7}$ & 0.1365210 & 0.156947 \\
\hline $\mathrm{X}_{8}$ & 0.1008560 & 0.084453 \\
\hline $\mathrm{X}_{9}$ & 0.1204480 & 0.090640 \\
\hline $\mathrm{X}_{10}$ & 0.1051940 & 0.099666 \\
\hline
\end{tabular}


Table 3. Eco-environmental development index weights of urban agglomerations in eastern Qinghai Province

\begin{tabular}{|c|c|c|}
\hline $\begin{array}{c}\text { Environment } \\
\text { al } \\
\text { Indicators }\end{array}$ & Xining & Haidong \\
\hline $\mathrm{Y}_{1}$ & 0.049134 & 0.112100 \\
\hline $\mathrm{Y}_{2}$ & 0.147659 & 0.240898 \\
\hline $\mathrm{Y}_{3}$ & 0.085244 & 0.080637 \\
\hline $\mathrm{Y}_{4}$ & 0.046138 & 0.066282 \\
\hline $\mathrm{Y}_{5}$ & 0.112388 & 0.069111 \\
\hline $\mathrm{Y}_{6}$ & 0.046300 & 0.081274 \\
\hline $\mathrm{Y}_{7}$ & 0.098513 & 0.075080 \\
\hline $\mathrm{Y}_{8}$ & 0.165141 & 0.159457 \\
\hline $\mathrm{Y}_{9}$ & 0.249483 & 0.115161 \\
\hline
\end{tabular}

Table 4. The comprehensive development level of the economy and ecological environment of the eastern urban agglomeration in Qinghai Province

\begin{tabular}{|c|c|c|c|c|}
\hline & \multicolumn{3}{|c}{$\begin{array}{c}\text { agglomeration in Qinghai Province } \\
\text { Comprehensive } \\
\text { economic } \\
\text { development level }\end{array}$} & $\begin{array}{c}\text { Comprehensive } \\
\text { development level } \\
\text { of ecological } \\
\text { environment }\end{array}$ \\
\hline Year & Xining & Haidong & Xining & Haidong \\
\hline 2005 & 0.121215 & 0.112905 & 0.369806 & 0.322121 \\
\hline 2006 & 0.199911 & 0.131003 & 0.350241 & 0.297201 \\
\hline 2007 & 0.214742 & 0.214395 & 0.338464 & 0.270057 \\
\hline 2008 & 0.257360 & 0.324819 & 0.281214 & 0.374109 \\
\hline 2009 & 0.282683 & 0.240022 & 0.342518 & 0.340792 \\
\hline 2010 & 0.382750 & 0.267010 & 0.297585 & 0.274751 \\
\hline 2011 & 0.428722 & 0.382677 & 0.511189 & 0.435169 \\
\hline 2012 & 0.483977 & 0.441935 & 0.375328 & 0.582920 \\
\hline 2013 & 0.544983 & 0.537045 & 0.329455 & 0.574091 \\
\hline 2014 & 0.594930 & 0.571054 & 0.327083 & 0.420129 \\
\hline 2015 & 0.629359 & 0.599956 & 0.326548 & 0.366790 \\
\hline 2016 & 0.674374 & 0.635624 & 0.538615 & 0.572473 \\
\hline 2017 & 0.663915 & 0.659462 & 0.600344 & 0.590482 \\
\hline 2018 & 0.722235 & 0.707485 & 0.615502 & 0.680498 \\
\hline 2019 & 0.760623 & 0.743413 & 0.659181 & 0.794120 \\
\hline
\end{tabular}

Table 5. Economic and ecological environment coordination degree of the eastern urban agglomeration in Qinghai Province

\begin{tabular}{|c|c|c|c|c|}
\hline & \multicolumn{2}{|c|}{ Xining } & \multicolumn{2}{c|}{ Haidong } \\
\hline & CDL & CL & CDL & CL \\
\hline 2005 & 0.553072 & B & 0.590912 & B \\
\hline 2006 & 0.856241 & W & 0.721407 & I \\
\hline 2007 & 0.902466 & Q & 0.973772 & Q \\
\hline 2008 & 0.996081 & Q & 0.990078 & Q \\
\hline 2009 & 0.981765 & Q & 0.940703 & Q \\
\hline 2010 & 0.968905 & Q & 0.999592 & Q \\
\hline 2011 & 0.984663 & Q & 0.991778 & Q \\
\hline 2012 & 0.968282 & Q & 0.962509 & Q \\
\hline 2013 & 0.882190 & W & 0.997778 & Q \\
\hline 2014 & 0.838339 & W & 0.954167 & Q \\
\hline 2015 & 0.809372 & W & 0.887042 & W \\
\hline 2016 & 0.975104 & Q & 0.994543 & Q \\
\hline 2017 & 0.994950 & Q & 0.993918 & Q \\
\hline
\end{tabular}

\begin{tabular}{|l|l|l|l|l|}
\hline 2018 & 0.987309 & Q & 0.999244 & Q \\
\hline 2019 & 0.989816 & Q & 0.997826 & Q \\
\hline
\end{tabular}

Table 6. The coordinated development level of the economy and ecological environment of the eastern urban agglomeration in Qinghai Province

\begin{tabular}{|c|c|c|c|c|}
\hline & \multicolumn{2}{|c|}{ Xining } & \multicolumn{2}{c|}{ Haidong } \\
\hline & CDL & CL & CDL & CL \\
\hline 2005 & 0.368490 & D & 0.358512 & D \\
\hline 2006 & 0.485316 & V & 0.393007 & D \\
\hline 2007 & 0.499625 & V & 0.485668 & V \\
\hline 2008 & 0.517911 & B & 0.588215 & B \\
\hline 2009 & 0.553985 & B & 0.522672 & B \\
\hline 2010 & 0.574099 & B & 0.520356 & B \\
\hline 2011 & 0.680256 & P & 0.636837 & P \\
\hline 2012 & 0.645000 & P & 0.702294 & I \\
\hline 2013 & 0.621056 & P & 0.744536 & I \\
\hline 2014 & 0.621675 & P & 0.687660 & P \\
\hline 2015 & 0.621967 & P & 0.654807 & P \\
\hline 2016 & 0.769022 & I & 0.775082 & I \\
\hline 2017 & 0.793056 & I & 0.788144 & I \\
\hline 2018 & 0.812637 & W & 0.832747 & W \\
\hline 2019 & 0.838256 & W & 0.875840 & W \\
\hline
\end{tabular}

\section{Notice:}

$\mathrm{CDL}=$ Coordinated development level

$\mathrm{CD}=$ Coordination level

$\mathrm{D}=$ Disorder

$\mathrm{V}=$ On the verge of disorder

$\mathrm{B}=$ Barely coordinated

$\mathrm{P}=$ Primary coordination

I=Intermediate coordination

$\mathrm{W}=$ Well coordinated

$\mathrm{Q}=$ Quality coordination

\section{Conclusions and countermeasures}

\subsection{Carry out corporate environmental credit evaluation}

The eastern urban agglomerations of Qinghai Province carry out environmental credit evaluations of enterprises, standardize enterprises to discharge pollution in accordance with laws and regulations, and punish or reward enterprises based on the results of pollution discharge. The administrative law enforcement agencies impose fines on companies with low environmental assessments and illegal emissions, and restrict their market access and financing. Various financial institutions have established a credit system for systematic environmental evaluation, taking environmental evaluation as an important indicator of the issuance of green credit; the Provincial Department of Industry and Information Technology shall refer to the results of the credit environmental evaluation when evaluating enterprises.

\subsection{Optimize the structure of green loans}

Bank branches of the eastern urban agglomeration of Qinghai Province should strongly support green projects 
such as photovoltaics, hydropower, and wind power when lending to enterprises, increase loans in green energy and resource recycling industries, and provide supporting credit support. At the same time, non-green projects are effectively eliminated, and green projects with non-uniform identification standards and irregular statistical standards are eliminated from the green loan statistical system one by one to ensure the green development of the eastern urban agglomeration in Qinghai Province and improve the effectiveness of support.

\subsection{Accelerate integration into the "Belt and Road" construction}

The eastern urban agglomeration of Qinghai Province should give full play to its late-comer advantages, develop advantageous industries, adjust industrial structure and exports, transform and adjust the main structure, product structure, trade structure, and market structure in the import and export trade, and transform the country and the "Belt and Road". Regional foreign trade development model. According to the Chengdong Economic Development Zone, cultivate a number of distinctive industrial bases; make overall plans, give priority to the development of cultural and tourism industries, and docking characteristic industries to achieve economic structure and industrial chain upgrades; strive to promote "one excellence and two highs" to protect the ecology; Leveraging on the "four links" strategy, we will expand total trade volume, accelerate infrastructure construction, and seize the opportunity of the country's use of Xining as a five-sixth hub for commercial and service-oriented cities, and promote Qinghai's specialty products to the world, so that the economy has vitality and vitality.

\subsection{Improve innovation and development capabilities}

Relying on leading enterprises or scientific research institutes, the eastern urban agglomeration of Qinghai Province efficiently builds a number of national specialized crowd-creation spaces, and creates an upgraded version of "double innovation", and innovative and entrepreneurial services for the purpose of promoting technological innovation and entrepreneurship and serving the real economy The establishment of the platform emphasizes the high degree of specialization of service objects and service content, which can efficiently configure and integrate various innovative elements to achieve precise incubation; promote the construction of university science parks, enhance the ability to drive regional economic development, and actively encourage university students to carry out innovation and entrepreneurship. And provide financial and technical assistance for college students' innovation and entrepreneurship.

\section{Acknowledgment}

Fund Project: National Social Science Foundation Project "Research on the Dynamic Mechanism and Path Selection of Green Development in Qaidam Basin" (19BMZ154)

\section{References}

1. Yang Yongfang, Wang Qin. Evaluation of the coordination between my country's ecological environment protection and regional economic highquality development[J]. Industrial Technology Economy, 2020, 39(11): 69-74.

2. Wang Yubao, Lu Yang, Wang Weihua. New progress in the research on the coordination and coupling of high-quality economic development and ecological environment protection[J]. Journal of Beijing University of Technology (Social Science Edition), 2019, 19(05): 84-94.

3. Zhang Yuanshuo. On the coordination between economic development and environmental protection[D]. University of International Business and Economics, 2016.

4. Li Cui, Luo Jiang, Li Qian. Legal considerations on the influencing factors and realization path of the coordinated development of economic growth and ecological environment protection in the western region $[\mathrm{J}]$. Reform and Strategy, 2016.(7).

5. Tong Sicong. Analysis of Coupling Degree of Economic Development and Ecological Environment Coupling in Western Regions[J]. Shanghai Energy Conservation, 2019(07):595-600.

6. Guo Shuaihui. Research on Urban Scale Distribution and Spatial Form in Lanxi Region [D] . Henan University of Technology, 2017.

7. Zhou Xiao, Wang Jianjun. Analysis on the spatial difference of the development level of ecological economy in Qinghai Province $[\mathrm{J}]$. Special Zone Economy, 2016.(3).

8. Sun Bingfen. Research on the spatiotemporal changes of the county economic development differences in Qinghai Province [D]. Qinghai Normal University, 2016.

9. Cheng Chenhui, Wang Xiaomei, Zhu Bin. Analysis of the difference in county economic development between Xining City and Haidong City in Qinghai Province $[\mathrm{J}]$. Special Zone Economy, 2016.(10).

10. Zhao Yingyan, $\mathrm{Yu}$ Fawen. Evaluation of the coordinated development of economy and ecological environment in Qinghai Province [J] Ecological Economy, 2015.31(8).

11. Wang Xiaopeng, Ding Shengxi. Evaluation of population, resources and environment carrying capacity in key development zones in Qinghai Province [ J ]. Mathematics in Practice and Understanding, 2016.46(6). 
12. Zhou Can. Research on the high-quality and coordinated development of regional economy: Taking Qinghai Province as an example [J]. Shanghai Business, 2020(06): 57-59.

13. Ding Shengxi, Tan Huiru, Ge Liya, Ren Haijing. Research on the coupling of economic growth and environmental quality in Qinghai Province based on multiple models[J]. Ecological Economy, 2017, 33(12): 150-154.

14. Qinghai Provincial Bureau of Statistics. Qinghai Provincial Statistical Yearbook (2005) [M]. Beijing: China Statistics Press, 2005.

15. Qinghai Provincial Bureau of Statistics. Qinghai Provincial Statistical Yearbook (2019) [M]. Beijing: China Statistics Press, 2019.

16. Qinghai Province Hydrology and Water Resources Survey Bureau. Qinghai Province Water Resources Bulletin. 2005.

17. Qinghai Province Hydrology and Water Resources Survey Bureau. Qinghai Province Water Resources Bulletin. 2018. 